\title{
Marc Boone, L'automne du Moyen Âge: Johan Huizinga et Henri Pirenne ou "plusieurs vérités pour la même chose»
}

\section{Pietro Arioli}

\section{(2) OpenEdition Journals}

Édition électronique

URL : http://journals.openedition.org/studifrancesi/7481

DOI : 10.4000/studifrancesi.7481

ISSN : 2421-5856

Éditeur

Rosenberg \& Sellier

\section{Édition imprimée}

Date de publication : 1 décembre 2009

Pagination : 605

ISSN : 0039-2944

\section{Référence électronique}

Pietro Arioli, « Marc Boone, L'automne du Moyen Âge: Johan Huizinga et Henri Pirenne ou «plusieurs vérités pour la même chose» », Studi Francesi [En ligne], 159 (LIII | III) | 2009, mis en ligne le 30 novembre 2015, consulté le 08 janvier 2021. URL : http://journals.openedition.org/studifrancesi/7481 ; DOI : https://doi.org/10.4000/studifrancesi.7481

Ce document a été généré automatiquement le 8 janvier 2021.

\section{cc) (†) $\odot$}

Studi Francesi è distribuita con Licenza Creative Commons Attribuzione - Non commerciale - Non opere derivate 4.0 Internazionale. 


\title{
Marc Boone, L'automne du Moyen Âge: Johan Huizinga et Henri Pirenne ou «plusieurs vérités pour la même chose»
}

\author{
Pietro Arioli
}

\section{RÉFÉRENCE}

MARC BOONE, L'automne du Moyen Âge: Johan Huizinga et Henri Pirenne ou «plusieurs vérités pour la même chose», dans Autour du XV siècle. Journées d'études en l'honneur d'Alberto Vàrvaro, cit., pp. 27-51.

1 M.B. explore l'aventure intellectuelle à l'origine de la publication de L'Automne du Moyen Âge. Dans ce but, il compare la figure de Johan Huizinga avec celle d'Henri Pirenne, son collègue et ami, en examinant d'une part leurs rapports personnels, d'autre part la perspective selon laquelle les deux médiévistes étudiaient l'histoire, le premier étant intéressé aux «réjouissances esthétiques de l'histoire culturelle», le second étant plutôt conservateur et positiviste. À partir donc de la phrase de Pirenne selon laquelle il y aurait "plusieurs vérités pour une même chose», M.B. s'interroge sur la réaction de Huizinga à cette affirmation. À travers le récit détaillé de la vie de Huizinga, étroitement nouée avec celle de Pirenne, Boone retrace enfin le parcours épistémologique et humain qui a mené à la rédaction de l'Automne et tire un bilan de l'influence de ces deux grands historiens sur les tendances actuelles de la recherche. 